\title{
Hashtags as a way to expedite the zakat supply chain
}

\section{Caturida Meiwanto Doktoralina $^{a^{*}}$, Zakaria Bahari ${ }^{b}$, Shahir Akram Hassan ${ }^{b}$, Nor Asmat Ismail ${ }^{c}$ and Sri Ayu Lailatul Mardiyah ${ }^{d}$}

\author{
${ }^{a}$ Faculty of Business and Economics, Universitas Mercu Buana, Jakarta, Indonesia \\ ${ }^{b}$ Centre For Islamic Development Management Studies (ISDEV) Universiti Sains Malaysia, Pulau Pinang, Malaysia \\ ${ }^{c}$ School of Social Sciences Universiti Sains Malaysia, Pulau Pinang, Malaysia \\ ${ }^{d}$ Faculty of Computer Science,Program Studi Sistem Informasi Universitas Mercu Buana, Jakarta, Indonesia
}

\section{H R O N I C L E}

\begin{tabular}{l}
\hline Article history: \\
Received June 7, 2019 \\
Received in revised format June \\
25,2019 \\
Accepted July 122019 \\
Available online \\
July 142019 \\
\hline Keywords: \\
Zakat hashtags \\
Zakat supply chain \\
Mustahiq economics \\
Zakat awareness \\
Marketing politics
\end{tabular}

\section{Introduction}

Zakat is one of the most powerful Islamic instruments to support the global poor, providing assistance to the financially weak and those who cannot afford their daily expenses. As an instrument of social welfare (Ayuniyyah et al., 2019; Weiss, 2002), those of a certain level of wealth are expected to pay a specific portion of their income (generally 2.5\%) as Zakat (Ciftci, 2019).

Within the boundaries of Islam, poverty can be defined as the failure of an individual to achieve any of the five basic human necessities of life as grounded in Maqasid Syariah: i) religion, ii) physical self, iii) knowledge, iv) dignity and v) wealth (Nadzri et al., 2012). Therefore, Zakat is of great importance for those who cannot fulfil their needs. Zakat is the way to reduce poverty (Ahmed et al., 2017; Shirazi, 2006; Yumna \& Clarke, 2011).

Different factors affect Zakat (Aryandra et al., 2018; Sedjati et al., 2018). Data integrity in social media and al-Quran online need information security (Almazrooie et al., 2018). 'Hashtags' (\#) are an

* Corresponding author

E-mail address: caturida meiwanto_drm@mercubuana.ac.id (C. M. Doktoralina)

(C) 2020 by the authors; licensee Growing Science.

doi: $10.5267 /$ j.uscm.2019.7.004 
important element of social media (Doktoralina \& Bahari, 2018), and an important relationship has developed between the two (Fox et al., 2015; Hawkins et al., 2014). Social media hashtags are used to increase awareness among Muslims regarding the importance of Zakat in both economics and politics. Enhancing the share of Zakat to grow the economy of the people has become an important issue.

Users of social media often demonstrate message solidarity with the help of 'hashtags', which include: '@zakatUS with \#zakatmalaysia and \#zakatindonesia and @zakatsg with \#zakatbruneidarussalam.' With the number of social media users increasing, it is likely that the \#zakat hashtag could be a critical element in promoting awareness of zakat payments among the Muslim people. Therefore, Zakat hashtags are related to awareness (Wisataone, 2018). Moreover, 'hashtags' are also related to marketing politics.

The ideas of politics and political understanding within the boundaries of Islam are meaningfully dissimilar in the overall view. According to Islam, all actions should be performed in accordance with the guidelines of sharia, as explained in the Al-Quran surah al-Isra (17:80). Politics are categorised into two major types: the politics of ethics, which normally deal with the human purpose to stay alive, and politics as a method to attain goals. Therefore, this study deals with the politics of ethics as it relates to Zakat and its relationship with Zakat hashtags.

The Zakat supply chain has a significant role in the Zakat system (Doktoralina \& Apollo, 2019; Larbani et al., 2011). Zakat awareness and marketing politics support the Zakat supply chain. An increase in awareness among the Muslim people increases Zakat payments, thus expediting the Zakat supply chain (Doktoralina et al., 2018) (See Fig. 1). Those who have a good awareness of the Zakat system are more involved in making Zakat payments compared with those who are less aware of the Zakat system and its benefits. Moreover, an increase in the Zakat supply chain increases the strength of the mustahiq economy. Mustahiq are those people who receive the Zakat. Not all people are mustahiq but certain Muslim communities or peoples (in accordance with Islamic instructions) with a low income level are considered mustahiq. The Zakat system leads to the empowerment of the mustahiq economy (Yuniar et al., 2018), thus increasing the welfare of mustahiq people.

The objective of this study is to examine the role of Zakat hashtags to promote the Zakat supply chain and mustahiq economics. Fig. 1 shows the relationship between the hashtags zakat, Zakat awareness, marketing politics, Zakat supply chain and mustahiq economics. The sub-objectives of the study are:

1. To investigate the effects of Zakat hashtags on Zakat awareness and marketing politics,

2. To investigate the effects of Zakat awareness and marketing politics on the Zakat supply chain,

3. To investigate the effects of the Zakat supply chain on mustahiq economics.

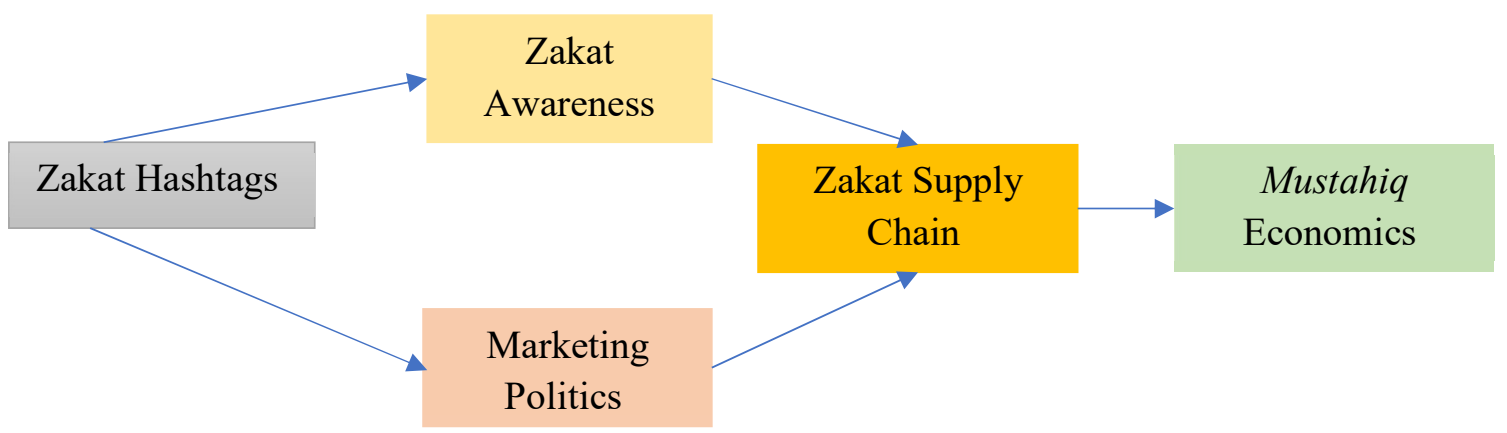

Fig. 1. Theoretical framework of the study showing the relationship between Zakat hashtags, Zakat awareness, marketing politics, Zakat supply chain and mustahiq economics. 


\section{Hypotheses Development}

Although various studies have been carried out on the Zakat system (Ahmad et al., 2014; Shinsuke, 2014; Sohag et al., 2015), this is one of the first studies to attempt to develop a framework to promote the Zakat supply chain and mustahiq economics.

At first, the hashtag was used only to categorise certain topics for easier searches. More social and creative users have followed, in which users apply hashtags to share textual data, pictures, videos and news links, making a forum for data information marketing politics (Khan et al., 2018). This creates an opportunity where the social reality is constructed with an exact meaning in order to help the objective of the message maker (Setiawan \& Santoso, 2017) - in this case, Zakat awareness. According to Islamic instructions, mustahiq people include: Fakir (indigent), Miskin (needy), Amil (mosque official who collects the tithe), Mualaf (recent convert to Islam), Riqb (slave), Gharimin (debtor/the indebted), Fisabilillah (those who fight for God's blessing) and Ibnu Sabil (the traveller who aims for the good of Allah SWT). This is illustrated in Fig. 2.

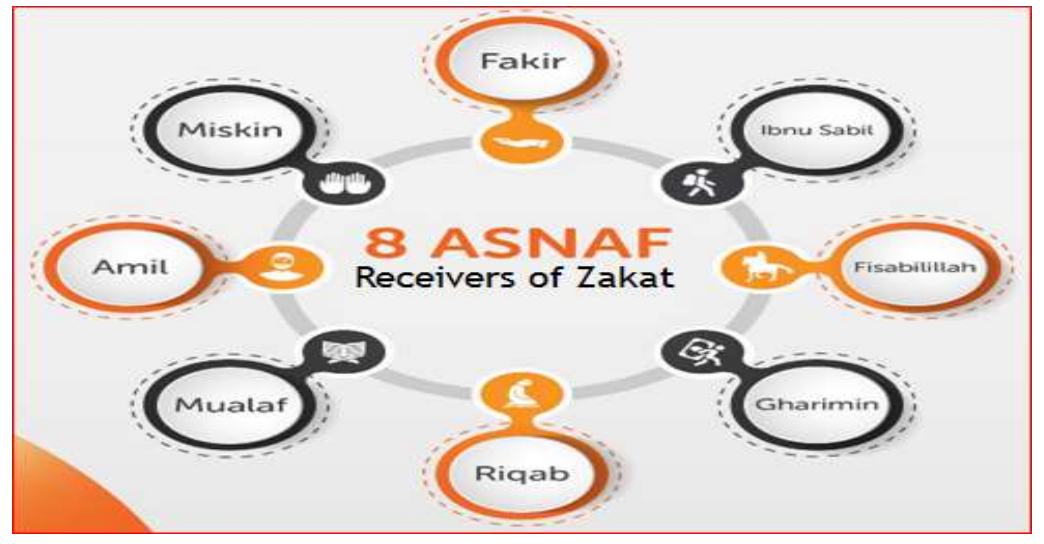

Fig. 2. Types of Mustahiq People for Zakat

According to Firdaus et al. (2012), one of the problems faced while collecting the Zakat is a lack of awareness among those who need to pay it. Awareness is thus the most important element of Zakat ( Doktoralina, 2016), as it directly affects the Zakat supply chain. An increase in Zakat collections increases the Zakat supply chain, which positively affects the mustahiq people, increasing the collective impact on mustahiq economics.

Zakat hashtags also have an effect on marketing politics. Marketing politics in Zakat must be ethical and follow Islamic instructions. Islam suggests that, as clarified in the Al-Quran surah al-Isra (17:80), all activities must be conducted under the guidelines of sharia.

The trend has changed as local cultures adopt different modern lifestyles, business behaviours (Dwityas \& Briandana, 2017), economic politics and forms of governance. However, hashtags have altered the process of da'wah performed by different Zakat institutions by increasing awareness among people regarding their responsibility for paying Zakat. Hashtags should be planned to enter social media without disregarding the original culture (Patra \& Khan, 2016).

With the help of marketing politics, cultures should be designed to sustain Zakat payments, which will lead to the development of mustahiq economics. Although the cultures of these countries (Doktoralina et al., 2018) should be preserved, the growth of information technology is causing them to change quickly (Sheldon et al., 2017; Yuliadi \& Nugroho, 2019). The Zakat hashtag could frame and generate a flexible, proactive chain to determine the value of awareness (Young-Ybarra \& Wiersema, 1999). 
Based on the above discussion, the following hypotheses are proposed:

H1: Zakat hashtags have a relationship with Zakat awareness.

H2: Zakat hashtags have a relationship with marketing politics.

H3: Zakat awareness has a relationship with the Zakat supply chain.

H4: Marketing politics has relationship with the Zakat supply chain.

H5: The Zakat supply chain has a relationship with mustahiq economics.

\section{Research Methodology}

\subsection{Research Design}

Choosing an appropriate design is the most important issue for any research study. This study employed the quantitative method to test objective theories (e.g. theoretical framework of the present study) by investigating the relationship between different variables (Creswell \& Creswell, 2017). The quantitative research method is also appropriate for testing hypotheses. As the data for this study were collected from one time, this study is also based on a cross-sectional research design.

\subsection{Sample Size}

A sample is a group of participants or individuals selected from a larger group or population for survey purposes (Salant et al., 1994). Selecting the appropriate sample size is imperative for reducing sampling errors. While there are numerous methods used to analyse sample size, this study followed Comrey and Lee's (2013) recommendations, according to which a "sample having less than 50 participants will observed to be a weaker sample; sample of 100 size will be weak; 200 will be adequate; sample of 300 will be considered as good; 500 very good whereas 1000 will be excellent." For this study we used a sample size of 300 .

\subsection{Sampling Procedure}

After selecting an appropriate sample size, the cluster sampling technique was used to distribute the questionnaires. According to previous studies, this is an effective technique for covering a widely dispersed population.

\subsection{Data Collection Procedure}

Ethics in research were addressed while collecting data. Respondents agreed to share data/information in the survey if they decided to participate (Bell et al., 2018; Cooper \& Schindler, 2013). None of the respondents felt compelled to contribute to the survey (Sekaran, 2003).

\section{Table 1}

Response from respondents

\begin{tabular}{lc}
\hline Response & Frequency/Rate \\
\hline Number of questionnaires distributed & 300 \\
Number of questionnaires returned & 170 \\
Number of useable questionnaires & 163 \\
Number of questionnaires excluded & 7 \\
Response rate & $56.6 \%$ \\
\hline Valid response rate & $54.3 \%$ \\
\hline
\end{tabular}

This is to reflect the true objective while the procedure of answering the survey questions. Furthermore, respondents who agreed to contribute were expected to be honest and truthful in their responses, without any misrepresentation of information (Sekaran \& Bougie, 2010). To distribute questionnaires, 
a list of respondents was obtained and respondents were selected randomly. Data collection is presented in Table 1. Initial data screening is shown in Table 2. This shows that the data contains no missing values and no outliers. However, normality is not an issue while using PLS (Reinartz et al., 2009).

Table 2

Initial Data Screening

\begin{tabular}{|c|c|c|c|c|c|c|c|c|c|}
\hline & No. & Missing & Mean & Median & Min & Max & SD & Kurtosis & Skewness \\
\hline $\mathrm{HZ1}$ & 1 & 0 & 4.967 & 6 & 1 & 7 & 1.908 & -0.701 & -0.663 \\
\hline HZ2 & 2 & 0 & 5.31 & 6 & 1 & 7 & 1.796 & -0.646 & -0.757 \\
\hline $\mathrm{HZ3}$ & 3 & 0 & 5.185 & 6 & 1 & 7 & 1.894 & -0.328 & -0.889 \\
\hline HZ4 & 4 & 0 & 5.011 & 6 & 1 & 7 & 1.862 & -0.838 & -0.602 \\
\hline HZ5 & 5 & 0 & 5.022 & 6 & 1 & 7 & 1.942 & -0.74 & -0.677 \\
\hline HZ6 & 6 & 0 & 4.984 & 6 & 1 & 7 & 1.786 & -0.832 & -0.558 \\
\hline HZ7 & 7 & 0 & 4.707 & 5 & 1 & 7 & 1.973 & -1.101 & -0.369 \\
\hline HZ8 & 8 & 0 & 4.886 & 5 & 1 & 7 & 1.837 & -0.795 & -0.584 \\
\hline HZ9 & 9 & 0 & 4.793 & 5 & 1 & 7 & 1.883 & -0.977 & -0.353 \\
\hline ZA1 & 10 & 0 & 4.973 & 5 & 1 & 7 & 1.921 & -0.993 & -0.476 \\
\hline ZA2 & 11 & 0 & 4.777 & 5 & 1 & 7 & 1.919 & -1.042 & -0.363 \\
\hline ZA3 & 12 & 0 & 5.185 & 6 & 1 & 7 & 1.879 & -0.47 & -0.835 \\
\hline ZA4 & 13 & 0 & 5.185 & 6 & 1 & 7 & 1.876 & -0.72 & -0.719 \\
\hline ZA5 & 14 & 0 & 4.984 & 6 & 1 & 7 & 1.861 & -0.652 & -0.67 \\
\hline ZA6 & 15 & 0 & 4.902 & 6 & 1 & 7 & 1.857 & -0.82 & -0.57 \\
\hline ZA7 & 16 & 0 & 4.864 & 5 & 1 & 7 & 1.811 & -0.63 & -0.642 \\
\hline ZA8 & 17 & 0 & 3.832 & 3 & 1 & 7 & 1.939 & -1.149 & 0.344 \\
\hline MP1 & 18 & 0 & 5.234 & 6 & 1 & 7 & 1.765 & -0.116 & -0.839 \\
\hline MP2 & 19 & 0 & 5.196 & 6 & 1 & 7 & 1.81 & -0.631 & -0.683 \\
\hline MP3 & 20 & 0 & 5.201 & 6 & 1 & 7 & 1.861 & -0.374 & -0.817 \\
\hline MP4 & 21 & 0 & 5.163 & 6 & 1 & 7 & 1.819 & -0.727 & -0.681 \\
\hline MP5 & 22 & 0 & 5.207 & 6 & 1 & 7 & 1.821 & -0.276 & -0.838 \\
\hline MP6 & 23 & 0 & 5.245 & 6 & 1 & 7 & 1.818 & -0.304 & -0.85 \\
\hline MP7 & 24 & 0 & 5.022 & 6 & 1 & 7 & 1.917 & -0.687 & -0.708 \\
\hline MP8 & 25 & 0 & 3.88 & 4 & 1 & 7 & 1.893 & -1.06 & 0.261 \\
\hline ZSC1 & 26 & 0 & 4.962 & 5 & 1 & 7 & 1.918 & -0.802 & -0.505 \\
\hline ZSC2 & 27 & 0 & 5.147 & 6 & 1 & 7 & 1.872 & -0.701 & -0.676 \\
\hline $\mathrm{ZSC} 3$ & 28 & 0 & 4.88 & 5 & 1 & 7 & 1.796 & -0.951 & -0.375 \\
\hline ZSC4 & 29 & 0 & 3.967 & 4 & 1 & 7 & 1.841 & -1.146 & 0.148 \\
\hline ZSC5 & 30 & 0 & 5.103 & 6 & 1 & 7 & 1.731 & -0.377 & -0.662 \\
\hline ME1 & 31 & 0 & 5.027 & 5 & 1 & 7 & 1.774 & -0.902 & -0.448 \\
\hline ME2 & 32 & 0 & 5.092 & 6 & 1 & 7 & 1.841 & -0.666 & -0.654 \\
\hline ME3 & 33 & 0 & 5.071 & 6 & 1 & 7 & 1.833 & -0.593 & -0.623 \\
\hline ME4 & 34 & 0 & 5.239 & 6 & 1 & 7 & 1.787 & -0.594 & -0.693 \\
\hline ME5 & 35 & 0 & 4.918 & 6 & 1 & 7 & 1.981 & -0.984 & -0.584 \\
\hline ME6 & 36 & 0 & 4.87 & 6 & 1 & 7 & 2.025 & -0.792 & -0.679 \\
\hline ME7 & 37 & 0 & 3.87 & 4 & 1 & 7 & 1.979 & -1.227 & 0.344 \\
\hline ME8 & 38 & 0 & 5.049 & 6 & 1 & 7 & 1.968 & -0.681 & -0.729 \\
\hline
\end{tabular}

\section{Data Analysis}

In recent decades, structural equation modelling (SEM) has emerged as the most useful and innovative statistical analysis procedure that has been developed in the social sciences (Henseler et al., 2014). These approaches are appropriate for a study that seeks to indirectly or directly estimate unobserved latent variables (Chin \& Todd, 1995). Fundamentally, SEM analytical methods employ numerous techniques; this study used the procedure of Henseler et al. (2009). It is based on two major steps. The first step is shown in Fig. 3. 


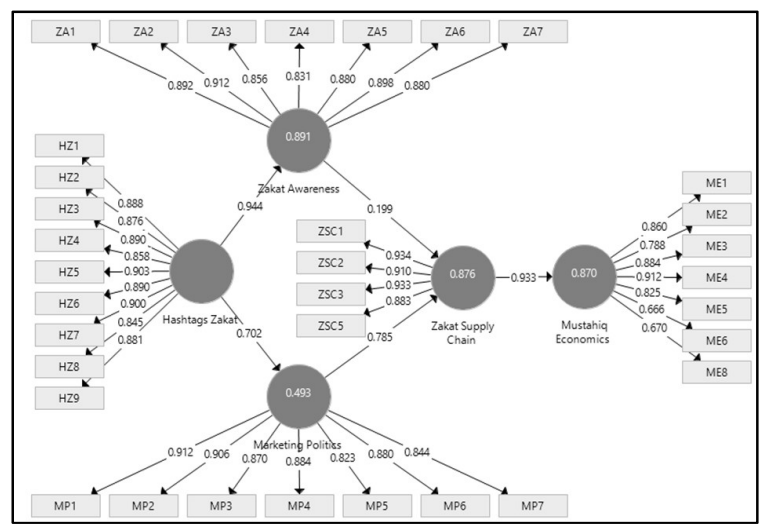

Fig. 3. Measurement model assessment

Table 3

Factor Loadings

\begin{tabular}{|c|c|c|c|c|c|}
\hline & & Mustahiq & & & \\
\hline & Hashtags Lakat & Economics & Varketing Politics & Zakat Awareness & Zakat Supply Chain \\
\hline $\mathrm{HZ1}$ & 0.888 & & & & \\
\hline $\mathrm{HZ2}$ & 0.876 & & & & \\
\hline $\mathrm{HZ3}$ & 0.890 & & & & \\
\hline HZ4 & 0.858 & & & & \\
\hline HZ5 & 0.903 & & & & \\
\hline HZ6 & 0.890 & & & & \\
\hline $\mathrm{HZ7}$ & 0.90 & & & & \\
\hline HZ8 & 0.845 & & & & \\
\hline $\mathrm{HZ9}$ & 0.881 & & & & \\
\hline ME1 & & 0.860 & & & \\
\hline ME2 & & 0.788 & & & \\
\hline ME3 & & 0.884 & & & \\
\hline ME4 & & 0.912 & & & \\
\hline ME5 & & 0.825 & & & \\
\hline ME6 & & 0.666 & & & \\
\hline ME8 & & 0.670 & & & \\
\hline MP1 & & & 0.912 & & \\
\hline MP2 & & & 0.906 & & \\
\hline MP3 & & & 0.870 & & \\
\hline MP4 & & & 0.884 & & \\
\hline MP5 & & & 0.823 & & \\
\hline MP6 & & & 0.880 & & \\
\hline MP7 & & & 0.844 & & \\
\hline ZA1 & & & & 0.892 & \\
\hline ZA2 & & & & 0.912 & \\
\hline ZA3 & & & & 0.856 & \\
\hline ZA4 & & & & 0.831 & \\
\hline ZA5 & & & & 0.880 & \\
\hline ZA6 & & & & 0.898 & \\
\hline ZA7 & & & & 0.880 & \\
\hline ZSC1 & & & & & 0.934 \\
\hline ZSC2 & & & & & 0.910 \\
\hline ZSC3 & & & & & 0.933 \\
\hline ZSC5 & & & & & 0.883 \\
\hline
\end{tabular}

All the values are under the acceptable range. As the factor loadings is above 0.5 (Hair et al., 2017). It is shown in Table 4.

\section{Table 4}

Alpha, CR and AVE

\begin{tabular}{lcccc}
\hline & Alpha & rho_A & CR & (AVE) \\
\hline Hashtags Zakat & 0.964 & 0.965 & 0.969 & 0.777 \\
Marketing Politics & 0.949 & 0.950 & 0.765 & 0.928 \\
Mustahiq Economics & 0.908 & 0.925 & 0.960 & 0.650 \\
Zakat Awareness & 0.951 & 0.951 & 0.772 \\
Zakat Supply Chain & 0.935 & 0.936 & 0.954 \\
\hline
\end{tabular}


After examining reliability and convergent validity, discriminant validity was examined using the instructions of Fornell and Larcker (1981), according to which the AVE root should be higher than other values. Table 5 shows that the AVE square roots are higher than all other values, thus confirming the discriminant validity. It is also examined with the help of cross-loadings (Table 6).

Table 5

AVE Square Root (Fornell \& Larcker, 1981)

\begin{tabular}{lccccc}
\hline & $\begin{array}{c}\text { Hashtags } \\
\text { Zakat }\end{array}$ & $\begin{array}{c}\text { Marketing } \\
\text { Politics }\end{array}$ & $\begin{array}{c}\text { Mustahiq } \\
\text { Economics }\end{array}$ & $\begin{array}{c}\text { Zakat } \\
\text { Awareness }\end{array}$ & $\begin{array}{c}\text { Zakat Supply } \\
\text { Chain }\end{array}$ \\
\hline Hashtags Zakat & $\mathbf{0 . 8 8 1}$ & & & & \\
Marketing Politics & 0.702 & $\mathbf{0 . 8 7 5}$ & & & \\
Mustahiq Economics & 0.732 & 0.797 & $\mathbf{0 . 8 0 6}$ & & $\mathbf{0 . 8 7 9}$ \\
Zakat Awareness & 0.744 & 0.709 & 0.756 & 0.755 & $\mathbf{0 . 7 1 5}$ \\
Zakat Supply Chain & 0.718 & 0.726 & 0.733 & & \\
\hline
\end{tabular}

Table 6

Cross-Loadings

\begin{tabular}{|c|c|c|c|c|c|}
\hline & Hashtags Zakat & Marketing Politics & Mustahiq Economics & Zakat Awareness & Zakat Supply Chain \\
\hline $\mathrm{HZ1}$ & 0.888 & 0.609 & 0.647 & 0.837 & 0.635 \\
\hline $\mathrm{HZ2}$ & 0.876 & 0.651 & 0.629 & 0.797 & 0.619 \\
\hline HZ3 & 0.890 & 0.603 & 0.622 & 0.824 & 0.619 \\
\hline HZ4 & 0.858 & 0.611 & 0.627 & 0.798 & 0.602 \\
\hline HZ5 & 0.903 & 0.673 & 0.707 & 0.877 & 0.698 \\
\hline HZ6 & 0.890 & 0.613 & 0.643 & 0.814 & 0.614 \\
\hline $\mathrm{HZ7}$ & 0.900 & 0.633 & 0.677 & 0.883 & 0.661 \\
\hline HZ8 & 0.845 & 0.538 & 0.578 & 0.782 & 0.571 \\
\hline HZ9 & 0.881 & 0.631 & 0.669 & 0.866 & 0.668 \\
\hline ME1 & 0.639 & 0.958 & 0.860 & 0.659 & 0.813 \\
\hline ME2 & 0.557 & 0.829 & 0.788 & 0.577 & 0.754 \\
\hline ME3 & 0.615 & 0.939 & 0.884 & 0.635 & 0.86 \\
\hline ME4 & 0.663 & 0.956 & 0.912 & 0.692 & 0.855 \\
\hline ME5 & 0.605 & 0.884 & 0.825 & 0.637 & 0.81 \\
\hline ME6 & 0.515 & 0.831 & 0.666 & 0.509 & 0.545 \\
\hline ME8 & 0.537 & 0.738 & 0.67 & 0.545 & 0.538 \\
\hline MP1 & 0.657 & 0.912 & 0.818 & 0.622 & 0.805 \\
\hline MP2 & 0.64 & 0.906 & 0.801 & 0.643 & 0.73 \\
\hline MP3 & 0.622 & 0.87 & 0.89 & 0.643 & 0.823 \\
\hline MP4 & 0.645 & 0.884 & 0.899 & 0.644 & 0.836 \\
\hline MP5 & 0.577 & 0.823 & 0.842 & 0.586 & 0.754 \\
\hline MP6 & 0.598 & 0.88 & 0.898 & 0.608 & 0.812 \\
\hline MP7 & 0.554 & 0.744 & 0.789 & 0.592 & 0.774 \\
\hline ZA1 & 0.846 & 0.591 & 0.646 & 0.892 & 0.649 \\
\hline ZA2 & 0.855 & 0.638 & 0.693 & 0.912 & 0.698 \\
\hline ZA3 & 0.797 & 0.629 & 0.637 & 0.856 & 0.669 \\
\hline ZA4 & 0.795 & 0.567 & 0.636 & 0.831 & 0.634 \\
\hline ZA5 & 0.829 & 0.651 & 0.674 & 0.880 & 0.681 \\
\hline ZA6 & 0.847 & 0.67 & 0.707 & 0.898 & 0.677 \\
\hline ZA7 & 0.837 & 0.611 & 0.655 & 0.880 & 0.635 \\
\hline ZSC1 & 0.695 & 0.858 & 0.869 & 0.693 & 0.934 \\
\hline ZSC2 & 0.635 & 0.869 & 0.839 & 0.702 & 0.910 \\
\hline ZSC3 & 0.681 & 0.869 & 0.87 & 0.713 & 0.933 \\
\hline ZSC5 & 0.615 & 0.79 & 0.837 & 0.655 & 0.883 \\
\hline
\end{tabular}

Confirmation of the first step of PLS-SEM (factor loadings, CR, AVE, convergent validity) allows for further testing of the hypotheses. In this process, a minimum t-value level of 1.96 was considered to test the hypotheses. Fig. 4 shows the process of hypotheses testing. The results are highlighted in Table 7. The results shown in Table 8 indicate that all relationships have a t-value greater than 1.96, thus confirming all hypotheses. Additionally, the beta values are positive for all hypotheses, demonstrating a direct relationship between variables. It shows that Zakat hashtags increase Zakat awareness and 
marketing politics, and that Zakat awareness and marketing politics increase the Zakat supply chain. The Zakat supply chain, in turn, increases the mustahiq economics.

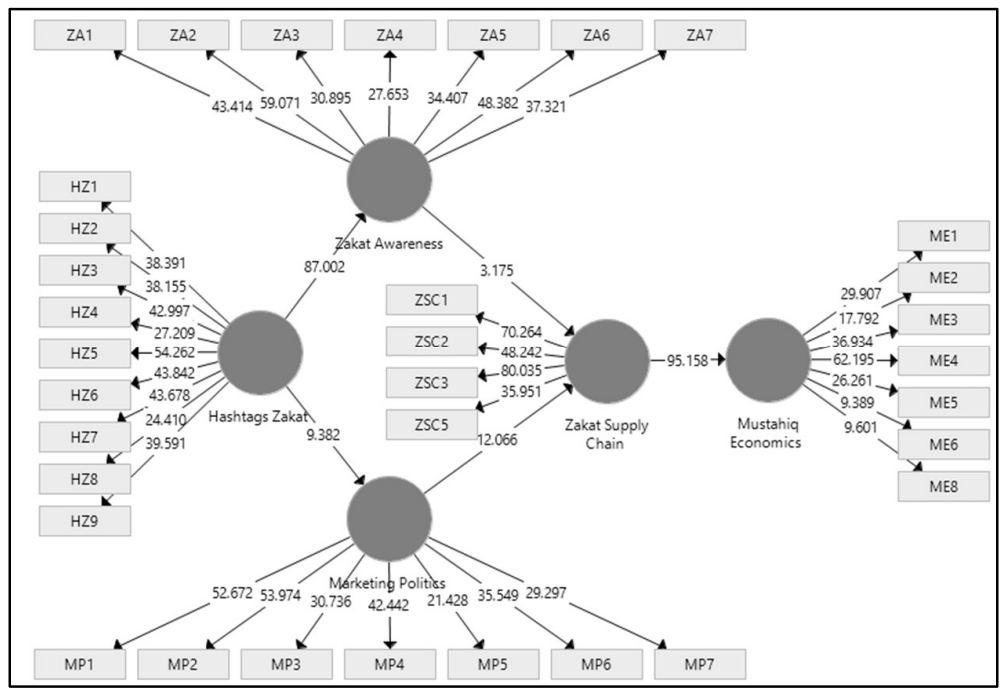

Fig. 4. Structural model assessment.

Table 7

The results of testing the hypotheses of the survey

\begin{tabular}{lccccc}
\hline & $(\mathrm{O})$ & Sample Mean $(\mathrm{M})$ & SD & T Statistics & P Values \\
\hline Hashtags Zakat $\rightarrow$ Marketing Politics & 0.702 & 0.699 & 0.075 & 9.382 & 0 \\
Hashtags Zakat $\rightarrow$ Zakat Awareness & 0.944 & 0.945 & 0.011 & 87.002 & 0 \\
Marketing Politics $\rightarrow$ Zakat Supply Chain & 0.785 & 0.778 & 0.065 & 12.066 & 0 \\
Zakat Awareness $\rightarrow$ Zakat Supply Chain & 0.199 & 0.204 & 0.063 & 3.175 & 0.002 \\
Zakat Supply Chain $\rightarrow$ Mustahiq Economics & 0.933 & 0.934 & 0.01 & 95.158 & 0 \\
\hline
\end{tabular}

It was also found that Zakat awareness and marketing politics play a mediating role between the hashtags Zakat and Zakat supply chain. Zakat supply chain also played a mediating role.

\section{Table 8}

The results of the mediation effect

\begin{tabular}{|c|c|c|c|c|c|}
\hline & (O) & (M) & SD & $\begin{array}{c}\mathbf{T} \\
\text { Statistics } \\
\end{array}$ & $\begin{array}{c}P \\
\text { Values }\end{array}$ \\
\hline Marketing Politics $\rightarrow$ Zakat Supply Chain $\rightarrow$ Mustahiq Economics & 0.732 & 0.727 & 0.062 & 11.778 & 0 \\
\hline Hashtags Zakat $\rightarrow$ Marketing Politics $\rightarrow$ Zakat Supply Chain $\rightarrow$ Mustahiq Economics & 0.514 & 0.505 & 0.045 & 11.426 & 0 \\
\hline Zakat Awareness $\rightarrow$ Zakat Supply Chain $\rightarrow$ Mustahiq Economics & 0.186 & 0.191 & 0.058 & 3.175 & 0.002 \\
\hline Hashtags Zakat $\rightarrow$ Zakat Awareness $\rightarrow$ Zakat Supply Chain $\rightarrow$ Mustahiq Economics & 0.175 & 0.18 & 0.055 & 3.199 & 0.001 \\
\hline Hashtags Zakat $\rightarrow$ Marketing Politics $\rightarrow$ Zakat Supply Chain & 0.551 & 0.541 & 0.047 & 11.706 & 0 \\
\hline Hashtags Zakat $\rightarrow$ Zakat Awareness $\rightarrow$ Zakat Supply Chain & 0.188 & 0.193 & 0.059 & 3.2 & 0.001 \\
\hline
\end{tabular}

\section{Conclusion}

The objective of this study was to examine the role of Zakat hashtags to promote the Zakat supply chain and mustahiq economics, as well as the roles of Zakat awareness and marketing politics. This study was an attempt to develop a framework that increases the Zakat supply chain and empowers mustahiq economics. The study findings, which show that Zakat hashtags play a major role in increasing Zakat awareness, represent a significant contribution to increasing awareness of Zakat payments among the general public. Zakat awareness and marketing politics expedite the payment of Zakat, automatically boosting the empowerment level of the Zakat supply chain and mustahiq economics. Zakat hashtags are vital social media elements that can effect positive changes on mustahiq economics, and it is hoped that this study will encourage Zakat collection institutions and the Indonesian government to promote Zakat payments and mustahiq economics. 


\section{References}

Ahmad, N. N., Tarmidi, M., Ridzwan, I. U., Hamid, M., \& Roni, R. (2014). The application of unified theory of acceptance and use of technology (UTAUT) for predicting the usage of e-zakat online system. International Journal of Science and Research (IJSR), 3(4), 63-70.

Ahmed, B. O., Johari, F., \& Abdul Wahab, K. (2017). Identifying the poor and the needy among the beneficiaries of zakat: Need for a zakat-based poverty threshold in Nigeria. International Journal of Social Economics, 44(4), 446-458.

Almazrooie, M., Samsudin, A., Gutub, A. A.-A., Salleh, M. S., Omar, M. A., \& Hassan, S. A. (2018). Integrity verification for digital Holy Quran verses using cryptographic hash function and compression. Journal of King Saud University-Computer and Information Sciences.

Aryandra, A., Basri, Y. Z., \& Mariyanti, T. (2018). Factors affecting internal control of zakat organizations in Tawhidi string relationship perspective. International Journal of Islamic Business \& Management, 2(1), 4966.

Ayuniyyah, Q., Pramanik, A. H., Saad, N. M., \& Ariffin, M. I. (2019). Zakat and education for poverty alleviation and income inequality reduction: A Case Study of West Java, Indonesia. ISLAMINOMICS, 9(1).

Bell, E., Bryman, A., \& Harley, B. (2018). Business research methods. Oxford university press.

Chin, W. W., \& Todd, P. A. (1995). On the use, usefulness, and ease of use of structural equation modeling in MIS research: a note of caution. MIS Quarterly, 237-246.

Ciftci, S. (2019). Islam, Social Justice, and Democracy. Politics and Religion. Cambridge University Press.

Comrey, A. L., \& Lee, H. B. (2013). A first course in factor analysis. Psychology press.

Cooper, D. R., \& Schindler, P. S. (2013). Business Research Methods (Twelfth Ed). McGraw-Hill/Irwin.

Creswell, J. W., \& Creswell, J. D. (2017). Research design: Qualitative, quantitative, and mixed methods approaches (4 edition). Sage publications.

Doktoralina, C., \& Apollo, A. (2019). The contribution of strategic management accounting in supply chain outcomes and logistic firm profitability. Uncertain Supply Chain Management, 7(2), 145-156.

Doktoralina, C. M. (2016). Relationship between extrinsic motivation and compliance to pay income zakat among academic people in Indonesia: Conceptual Framework Analysis. In The 9 th international Workshop of Development of Islam (WAPI-9) (pp. 15-19). Universiti Sains Malaysia.

Doktoralina, C. M., \& Bahari, Z. (2018). Hasthag (\#) Zakat Plays a Role in Marketing Politics. In The 13th IDMAC International Islamic Development Management Conference (IDMAC) (p. 13). Malaysia.

Doktoralina, C. M., Bahari, Z., \& Abdullah, S. R. (2018). Mobilisation of income zakat payment in Indonesia. Jurnal Ekonomi Dan Bisnis Islam, 3(2), 179-194.

Doktoralina, C. M., Bahari, Z., Ismail, N. A., Herliansyah, Y., \& Putri, G. P. (2018). Role of accounting zakat as a support function in supply chain management: A resurrection of the Islamic economy. International Journal of Supply Chain Management, 7(5), 336-342.

Dwityas, N. A., \& Briandana, R. (2017). Social media in travel decision making process. International Journal of Humanities and Social Science, 7(7), 291-292.

Firdaus, M., Beik, I. S., Irawan, T., \& Juanda, B. (2012). Economic estimation and determinations of Zakat potential in Indonesia. Jeddah: Islamic Research and Training Institute.

Fornell, C., \& Larcker, D. F. (1981). Evaluating structural equation models with unobservable variables and measurement error. Journal of Marketing Research, 18(1), 39-50.

Fox, J., Cruz, C., \& Lee, J. Y. (2015). Perpetuating online sexism offline: Anonymity, interactivity, and the effects of sexist hashtags on social media. Computers in Human Behavior, 52, 436-442.

Hair, J., Hollingsworth, C. L., Randolph, A. B., \& Chong, A. Y. L. (2017). An updated and expanded assessment of PLS-SEM in information systems research. Industrial Management \& Data Systems, 117(3), 442-458.

Haseeb, M., Hussain, H. I., Ślusarczyk, B., \& Jermsittiparsert, K. (2019). Industry 4.0: A solution towards technology challenges of sustainable business performance. Social Sciences, 8(5), 154.

Hawkins, C. M., Duszak, R., \& Rawson, J. V. (2014). Social media in radiology: early trends in Twitter microblogging at radiology's largest international meeting. Journal of the American College of Radiology, 11(4), 387-390.

Henseler, J., Dijkstra, T. K., Sarstedt, M., Ringle, C. M., Diamantopoulos, A., Straub, D. W., ... Calantone, R. J. (2014). Common beliefs and reality about PLS: Comments on Rönkkö and Evermann (2013). Organizational Research Methods, 17(2), 182-209.

Henseler, J., Ringle, C. M., \& Sinkovics, R. R. (2009). The use of partial least squares path modeling in international marketing. In New challenges to international marketing (pp. 277-319). Emerald Group Publishing Limited. 
Khan, M. L., Zaher, Z., \& Gao, B. (2018). Communicating on Twitter for Charity: Understanding the Wall of Kindness Initiative in Afghanistan, Iran, and Pakistan. International Journal of Communication, 12, 25.

Larbani, M., Mohammed, O. M., \& Olaniyi, N. O. (2011). The Problem Facing the Agricultural Sector in Nigeria and the Prospect of Zakat-Muzara'ah-Supply Chain Model (ZMSCM). International Islamic University Malaysia, Malaysia.[Google Scholar].

Nadzri, F. A. A., Rahman, A., \& Rashidah \& Omar, N. (2012). Zakat and poverty alleviation: Roles of zakat institutions in Malaysia. International Journal of Arts and Commerce, 1(7), 61-72.

Patra, S. K., \& Khan, S. (2016). Politics as "Popular Culture" \& its Digital Manifestation: An Indian State Election \& A Few Twitter\# Hasthag Trends. International Journal of Communication Research, 6(2).

Reinartz, W., Haenlein, M., \& Henseler, J. (2009). An empirical comparison of the efficacy of covariance-based and variance-based SEM. International Journal of Research in Marketing, 26(4), 332-344.

Salant, P., Dillman, I., \& Don, A. (1994). How to conduct your own survey.

Sedjati, D. P., Basri, Y. Z., \& Hasanah, U. (2018). Analysis of Factors Affecting the Payment of Zakat in Special Capital Region (DKI) of Jakarta. International Journal of Islamic Business \& Management, 2(1), 24-34.

Sekaran, U. (2003). Towards a guide for novice research on research methodology: Review and proposed methods. Journal of Cases of Information Technology, 8(4), 24-35.

Sekaran, U., \& Bougie, R. (2010). Theoretical framework in theoretical framework and hypothesis development. Research Methods for Business: A Skill Building Approach, 80.

Setiawan, V. A., \& Santoso, B. (2017). Analisis Framing Pemberitaan Dahlan Iskan Dalam Kasus Dugaan Korupsi Gardu Induk Listrik Di Koran Jawa Pos Edisi Bulan Juni-Agustus 2015. Universitas Muhammadiyah Surakarta.

Sheldon, P., Rauschnabel, P. A., Antony, M. G., \& Car, S. (2017). A cross-cultural comparison of Croatian and American social network sites: Exploring cultural differences in motives for Instagram use. Computers in Human Behavior, 75(October 2017), 643-651. https://doi.org/https://doi.org/10.1016/j.chb.2017.06.009

Shinsuke, N. (2014). Resuscitation of the Antique Economic System or Novel Sustainable System? Revitalization of the Traditional Islamic Economic Institutions (Waqf and Zakat) in the Postmodern Era. Kyoto Bulletin of Islamic Area Studies, 7(March), 3-19. Retrieved from http://www.asafas.kyotou.ac.jp/kias/pdf/kb7/04esf1_01_nagaoka.pdf

Shirazi, N. S. (2006). Providing for the resource shortfall for poverty elimination through the institution of Zakat in low-income Muslim countries. International Journal of Economics, Management and Accounting, 14(1), $1-27$.

Sohag, K., Mahmud, K. T., Alam, F., \& Samargandi, N. (2015). Can zakat system alleviate rural poverty in Bangladesh? A propensity score matching approach. Journal of Poverty, 19(3), 261-277.

Weiss, H. (2002). Zakat and the question of Social Welfare. Social Welfare in Muslim Societies in Africa. Nordiska Afrikainstitutet.

Wisataone, V. (2018). Marketing Communication of Non-profit Organizations A Content Analysis on Instagram Posts of@ rumahzakat. In International Conference on Media and Communication Studies (ICOMACS 2018).

Young-Ybarra, C., \& Wiersema, M. (1999). Strategic flexibility in information technology alliances: The influence of transaction cost economics and social exchange theory. Organization Science, 10(4), 439-459.

Yuliadi, B., \& Nugroho, A. (2019). Integration between management capability and relationship capability to boost supply chain project performance. International Journal of Supply Chain Management, 8(2), 241-252.

Yumna, A., \& Clarke, M. (2011). Integrating zakat and Islamic charities with microfinance initiative in the purpose of poverty alleviation in Indonesia. In Proceeding 8th International Conference on Islamic Economics and Finance, Center for Islamic Economics and Finance, Qatar Faculty of Islamic Studies, Qatar Foundation.

Yuniar, G. N., Hanifah, H., \& Muljarijadi, B. (2018). Model management zakat productive for Mustahik Empowerment (Case Study: Rumah Amal Salman ITB and DPU Daarut Tauhid, Bandung, Indonesia). AFEBI Islamic Finance and Economic Review, 2(02).

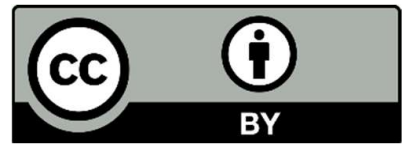

(C) 2019 by the authors; licensee Growing Science, Canada. This is an open access article distributed under the terms and conditions of the Creative Commons Attribution (CC-BY) license (http://creativecommons.org/licenses/by/4.0/). 